\title{
Genetic homogeneity in the seagrass Cymodocea nodosa at its northern Atlantic limit revealed through RAPD
}

\author{
Filipe Alberto*, Leonardo Mata, Rui Santos \\ Centre of Marine Sciences-FCMA, Universidade do Algarve, Campus de Gambelas, 8000 Faro, Portugal
}

\begin{abstract}
Random amplified polymorphic DNA (RAPD) markers were used to analyse the genetic variability of the dioecious seagrass Cymodocea nodosa Ucria (Ascherson) in the Ria Formosa lagoon, Portugal, the species' northern limit in the Atlantic. Three individuals from each of 6 meadows were genotyped with 28 primers. Meadows described previously as having flower marks were compared with meadows where flowers did not occur. A single polymorphic band, specific for one meadow, was observed in a total of 177 fragments. The lack of genetic variability among meadows both with and without flower indicates that flower production is not associated with a higher level of genetic variation. The genetic homogeneity of $C$. nodosa in the Ria Formosa suggests a founder effect, produced by a single or a limited number of migrants composing the colonising gene pool. This hypothesis is supported by the geographic isolation from other populations as the nearest populations lie more than $300 \mathrm{~km}$ away from the Ria Formosa. The lack of reproductive success of $C$. nodosa in Ria Formosa natural park and its low genetic variability are important factors in the conservation of this species since recolonisation can only occur through vegetative growth.
\end{abstract}

KEY WORDS: Cymodocea nodosa $\cdot$ RAPD - Genetic variability $\cdot$ Isolated population

Resale or republication not permitted without written consent of the publisher

The Ria Formosa lagoon is a natural park that constitutes the geographic limit of distribution for the dioecious seagrass Cymodocea nodosa in the North Atlantic (Cunha 1994). This park is relatively isolated with the nearest populations located at more than $300 \mathrm{~km}$ away, in Northern Africa and the Mediterranean Sea.

Although no complete study of reproductive phenology has so far been conducted in the Ria Formosa meadows, previous work has shown a reduced presence of reproductive structures when compared to other Mediterranean and Canary Island populations (Caye \& Meinesz 1985, Buia \& Mazzella 1991, Terrados

*E-mail: falberto@ualg.pt
1993, Reyes et al. 1995). The flower marks observed on rhizomes (diagnostic for previous flowering) were only observed in two of the sites studied, which were both associated with highly dynamic sandy substrate (Cunha 1994).

Analyses of the population genetic variability of Cymodocea nodosa can reveal the importance of sexual reproduction in the Ria Formosa meadows. Both monolocus codominant markers such as allozymes (Capiomont et al. 1996, Waycott et al. 1997, Ruckelshaus 1998) and microsatellites (Procaccini \& Mazella 1998, Reusch et al. 1999a,b,c, Reusch 2001) as well as multilocus dominant markers such as DNA fingerprinting (Alberte et al. 1994) and random amplified polymorphic DNA (RAPD) (Williams et al. 1990, Waycott 1995, 1998, Procaccini \& Mazella 1996, Kirsten et al. 1998) have been used to assess genetic diversity of seagrasses. RAPD analysis is a PCR technique that leads to different banding patterns when genomic regions vary in the presence/absence of complementary primer annealing sites. This method provides an easy and economic way to amplify DNA that may be variable among samples and leads to specific banding patterns for each individual (Hadrys et al. 1992). Moreover, as it addresses the whole genome, it presents a greater potential to detect DNA sequence variability than monolocus markers (Lui \& Furnier 1993). For example, RAPDs have revealed intrapopulation variability in Posidonia australis whilst previous allozyme studies found none (Waycott 1998). Procacini \& Mazzella (1996) also used RAPDs to compare the genetic diversity of $C$. nodosa and $P$. oceanica in the Mediterranean Sea.

In this study, we used RAPD markers to assess the level of genetic variability in Cymodocea nodosa in the Ria Formosa. To evaluate a possible relationship between genetic diversity of a meadow and flower production, the sites studied by Cunha (1994) were analysed. 


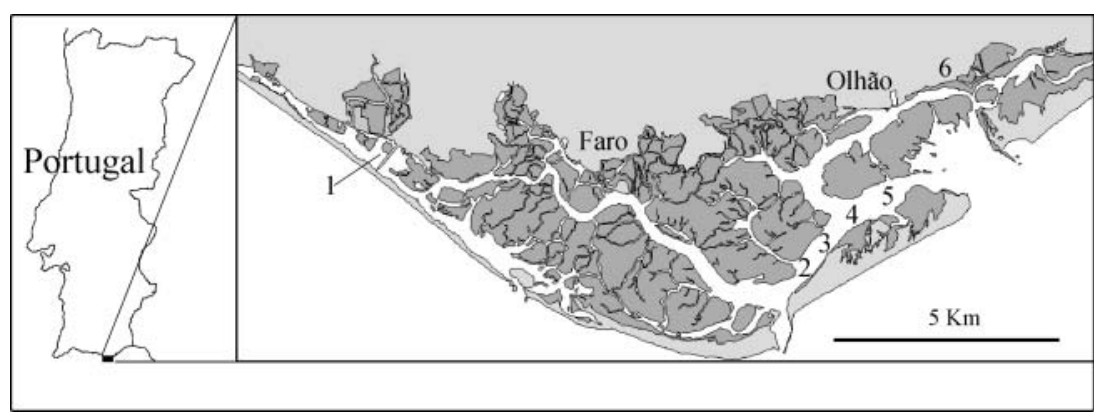

Fig. 1. Geographical location of Ria Formosa (Faro, Portugal), with location of study sites. Cymodocea nodosa meadows are: 1, Ponte; 2, Cações; 3, Daniel; 4, Culatra; 5, Areais; 6, Moinho

Material and methods. Sampling was conducted in the western and central sectors of the Ria Formosa at 6 locations: Ponte, Daniel, Cações, Culatra, Areais and Moinho, separated by distances of 0.5 to $10 \mathrm{~km}$ (Fig. 1). The 2 sites where flowering was previously described were the Cações and Areais (Cunha 1994).

At each meadow a $30 \mathrm{~m}$ transect was laid parallel to the shore at a depth of about $1.5 \mathrm{~m}$. Three Cymodocea nodosa samples, separated by $15 \mathrm{~m}$, were collected along the transect.

The samples were then transported to the laboratory and washed thoroughly with sterilised salt water and $0.01 \%$ SDS detergent. Leaf meristems were then dissected out and stored at $-80^{\circ} \mathrm{C}$. DNA was extracted using the Nucleon Phytopure DNA extraction Kit (Amersham). The DNA sample concentration and quality was checked using $1 \%$ agarose gel electrophoresis followed by ethidium bromide staining.

Eighty-four 10-mer primers (Operon Technologies Inc., California, Kits A, K, L, M and N) were screened for amplification with Cymodocea nodosa DNA. Twentyfive $\mu \mathrm{l}$ amplifications were performed using $2.5 \mu \mathrm{l}$ of $10 \times$ Taq DNA polymerase buffer $(100$ $\mathrm{mM}$ Tris $\mathrm{HCl} \mathrm{pH} 9.0,500 \mathrm{mM} \mathrm{KCl}, 15$ $\left.\mathrm{mM} \mathrm{MgCl}_{2}\right), 150 \mu \mathrm{M}$ of dATP, dGTP, $\mathrm{dCTP}$ and dTTP, $0.4 \mu \mathrm{M}$ of primer, 1 unit of Taq DNA polymerase (Pharmacia Biotech) and $20 \mathrm{ng}$ of genomic DNA. PCR amplifications were programmed for a 1.5 min denaturation cycle at $94^{\circ} \mathrm{C}$, 35 cycles of $30 \mathrm{~s}$ at $94^{\circ} \mathrm{C}, 30 \mathrm{~s}$ at $36^{\circ} \mathrm{C}$ and $30 \mathrm{~s}$ at $72^{\circ} \mathrm{C}$, followed by a final elongation step of $10 \mathrm{~min}$ at $72^{\circ} \mathrm{C}$. The ramp time of PCR reactions was set to $0.6^{\circ} \mathrm{C}$ $\mathrm{s}^{-1}$. Amplification products were resolved using agarose gel electrophoresis $(1.8 \%)$ in TBE buffer (45 mM Tris Borate, $1 \mathrm{mM}$ EDTA) and visualised under UV light after ethidium bromide staining. Gels were photographed using a Kodak
DC 200 digital camera. Bands were scored for presence/absence and all amplifications were tested for reproducibility by duplicating reactions at least twice. All non-reproducible bands were not included in the analysis.

Results and discussion. Out of 84,28 primers revealed clear banding patterns. These 28 primers amplified 177 fragments, of which 176 were common to all the analysed samples. A single polymorphic fragment was found for all the 3 samples at the Moinho site. This represents only $0.6 \%$ of total amplified fragments (Fig. 2). The high number of primers used suggests that the Cymodocea nodosa meadows of Ria Formosa are at least predominantly constituted by a single large genet. No relationship was found between genetic variability and the presence of flower marks in the vertical rhizomes.

However, care must be taken when using RAPDs to assess the genetic variability of populations because RAPDs are dominant multilocus markers and thus no distinction can be made between homozygous and heterozygous genotypes. This may hide some variability at the individual level and it is therefore not possible to conclusively state that all shoots come from the same genet by clonal propagation.

The homogenous RAPD pattern found among meadows with and without flower marks indicates that flowering is not associated with an increased genetic variation. This result may also add weight to the evidence that the number of genotypes in the Ria Formosa is very low. Such genetic homogeneity leaves very little variation for genetic recombination to produce

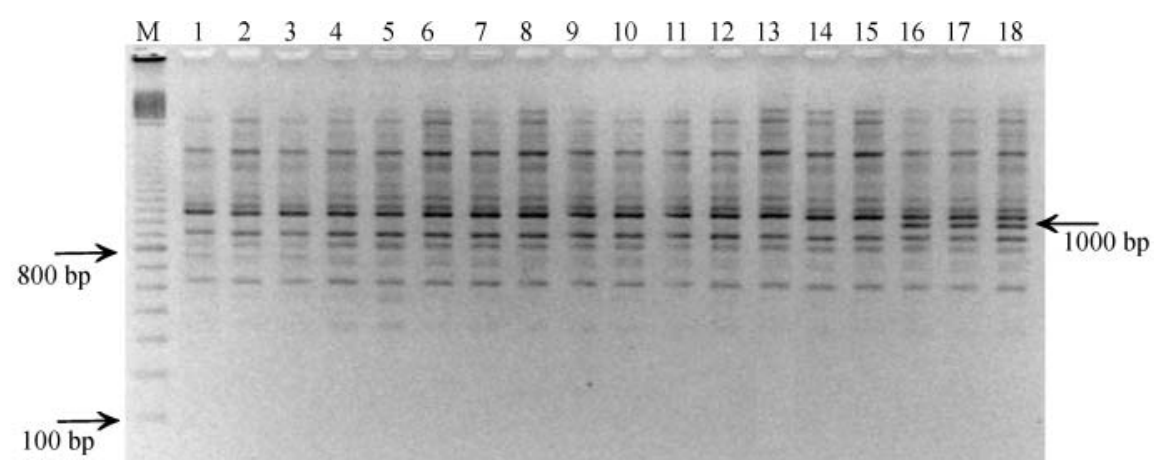

Fig. 2. RAPD amplifications of Cymodocea nodosa from 6 sites in Ria Formosa using primer OPM3. Three samples were analysed at each site: Ponte, lanes 1-3; Caçãoes, lanes 4-6; Daniel, lanes 7-9; Culatra, lanes 10-12; Areais, lanes 13-15 and Moinho, lanes 16-18. Lane $\mathrm{M}$ is the $100 \mathrm{bp}$ molecular size marker (Amersham-Pharmacia). One arrow shows the $1000 \mathrm{bp}$ polymorphic fragment, specific for the Moinho site 
genotypically novel offspring. In contrast to these results, Procaccini \& Mazzela (1996) found high levels of RAPD genetic variability in Cymodocea nodosa from the island of Ischia (Gulf of Naples, Italy) a population known to reproduce sexually (Procaccini \& Mazzela 1996).

The high level of genetic homogeneity of Cymodocea nodosa suggests that a founder effect of a migrant or a limited number of migrants was associated with the colonisation of Ria Formosa. This hypothesis is supported by the geographic isolation from other populations as the nearest $C$. nodosa sources lie more than $300 \mathrm{~km}$ away.

The polymorphic fragment found in all the Moinho meadow samples is evidence that some genetic variability exists. However, this polymorphic fragment could have been produced by the propagation of a single somatic mutation (Klekowski 1997). Theoretically a single mutation may produce a polymorphic RAPD marker.

The lack of reproductive success of Cymodocea nodosa in the Ria Formosa natural park and its low genetic variability are important factors in the conservation of this species. Major disturbances such as channel dredging, a common activity in the Ria Formosa system, cause extensive damage to $C$. nodosa meadows. Since sexual reproduction is not successful, disturbed areas will only recover by horizontal vegetative propagation from residual meadows. Consequently, all plans and management affecting the seagrass habitat in the Ria Formosa should consider $C$. nodosa dynamics in a metapopulation perspective (i.e. the seagrass patch extinction and recolonisation) with selected patches preserved to allow vegetative recolonisation in disturbed areas.

Acknowledgements. We thank Claire Billot and Martin Billingham for comments on the manuscript.

\section{LITERATURE CITED}

Alberte RS, Suba GK, Procaccini G, Zimmerman RC, Fain SR (1994) Assessment of genetic diversity of seagrass populations using DNA fingerprinting: implications for population stability and management. Proc Natl Acad Sci USA 91:1049-1053

Buia MC, Mazzella L (1991) Reproductive phenology of the mediteranean seagrasses posidonia oceanica (L.) Delile, Cymodocea nodosa (Ucria) Aschers., and Zostera noltii Hornem. Aquat Bot 40:343-362

Capiomont A, Sandmeier M, Caye G, Meinesz A (1996) Enzyme polymorphism in Posidonia oceanica, a seagrass endemic to the Mediterranean. Aquat Bot 54:265-277

Caye G, Meinesz A (1985) Observations of the vegetative development, flowering and seeding of Cymodocea no-

Editorial responsibility: Otto Kinne (Editor),

Oldendorf/Luhe, Germany dosa (Ucria) Acherson on the Mediterranean coasts of France. Aquat Bot 22:277-289

Cunha A (1994) Aplicação das técnicas de reconstrução ao estudo da dinâmica populacional de Cymodocea nodosa. Tese de mestrado em estudos marinhos e costeiros, Universidade do Algarve

Hadrys H, Balick M, Schierwater B (1992) Applications of random amplified polymorphic DNAs (RAPDS) in molecular ecology. Mol Ecol 1:55-63

Kirsten JH, Dawes CJ, Cochrane BJ (1998) Random amplified polymorphism detection (RAPD) reveals high genetic diversity in Thalassia testudinum banks ex Köning (turtlegrass). Aquat Bot 61:269-287

Klekkowski JR Jr (1997) Somatic mutation theory of clonality. In: de Kroon H, van Groenendael J (eds) The ecology and evolution of clonal plants. Bachuys, Leiden, p 227-241

Lui Z, Furnier GR (1993) Comparison of alozyme, RFLP, and RAPD markers for revealing genetic variation within and between trembling aspen and bigtoth aspen. Theor Appl Genet 87:97-105

Procaccini G, Mazzella L (1996) Genetic variability and reproduction in two Mediterranean seagrasses. Seagrass biology: proceedings of an international workshop. Rottnest Island, Western Australia, p 85-92

Procaccini G, Mazzella L (1998) Population genetic structure and gene flow in the seagrass Posidonia oceanica assessed using microsatellite analysis. Mar Ecol Prog Ser 169:133-141

Reusch TBH (2001) Pollination in the marine realm: microsatellites reveal high outcrossing rates and multiple paternity in eelgrass Zostera marina. Heredity 85:459-464

Reusch TBH, Boström C, Stam WT, Olsen JL (1999a) An ancient eelgrass clone in the Baltic Sea. Mar Ecol Prog Ser 183:301-304

Reusch TBH, Hukriede W, Stam WT, Olsen JL (1999b) Differentiating between clonal growth and limited gene flow using spatial autocorrelation of microsatellites. Heredity 83:120-126

Reusch TBH, Stam WT, Olsen JL (1999c) Microsatellite loci in eelgrass Zostera marina reveal marked polymorphism within and among populations. Mol Ecol 8:317-322

Reyes J, Sansón M, Afonso-Carrillo J (1995) Distribution and reproductive phenology of the seagrass Cymodocea nodosa (Ucria) Ascherson in the Canary islands. Aquat Bot 50:171-180

Ruckelshaus MH (1998) Spatial scale of genetic structure and an indirect estimate of gene flow in eelgrass, Zostera marina. Evolution 52:330-343

Terrados J (1993) Sexual reproduction and seed banks of Cymodocea nodosa (Ucria) Ascherson meadows on the southeast Mediterranean coast of Spain. Aquat Bot 46: 293-299

Waycott M (1995) Assessment of genetic variation and clonality in the seagrass Posidonia australis using RAPD and allozyme analysis. Mar Ecol Prog Ser 116:289-295

Waycott M (1998) Genetic variation, its assessment and implications to the conservation of seagrasses. Mol Ecol 7: 793-800

Waycott M, James SH, Walker DI (1997) Genetic variation within and between populations of Posidonia australis, a hydrophilous, clonal seagrass. Heredity 79:408-417

Williams JGK, Kubelik AR, Livak KJ, Rafalski JA, Tingey S (1990) DNA polymorphisms amplified by arbitrary primers are useful as genetic markers. Nucleic Acids Res 18: $6531-6535$

Submitted: March 21, 2001, Accepted: July 19, 2001

Proofs received from author(s): October 1, 2001 